\section{Singapore makes efforts to sustain biodiversity}

Sir-Agoramoorthy and Hsu in Correspondence (Nature 410, 144; 2001) express the fear that, although Singapore is creating a genome project costing S\$62 million (US\$35 million) over five years, it is ignoring some serious environmental issues.

They suggest that the number of future students of ecology and conservation in Singapore may fall, and rightly point out that, as an economic giant, Singapore has the responsibility to care for its natural environment and to help to conserve natural resources in neighbouring 'mega-diversity' countries.

They mention the government's conservation fund and Wildlife Reserves Singapore. These are not, however, the only large and long-standing conservation efforts under way. For example, the National University of Singapore (NUS) has been very active in conservation work and biodiversity research for some 30 years. In 1998, the Raffles Museum for Biodiversity Research was established at the NUS, with a budget of about $S \$ 2.7$ million, specifically to promote research on biodiversity and to deal with conservation issues in collaboration with the Singapore National Parks Board. These institutions have hosted hundreds of researchers from many countries who study biodiversity in Southeast Asia.

Between 1994 and 1999, NUS staff and students published some 300 articles, many in the leading scientific journals of their fields (Ng, P. K. L. National Science Museum Monographs (Tokyo) 18,2-23;2000). The NUS itself publishes the Raffles Bulletin of Zoology, an international, peer-reviewed journal of faunal studies in Southeast Asia. The Raffles Museum for Biodiversity Research has been involved in joint research and training projects with neighbouring countries, notably Brunei, China, Indonesia, Malaysia, the Philippines, Sri Lanka, Taiwan, Thailand and Vietnam. Further, a new public exhibit gallery aimed at promoting public awareness and education in conservation opened on 15 June 2001 (see http:// www.rmbr. nus.edu.sg).

We have been impressed by the enthusiasm of numerous graduate students dedicated to ecology, biodiversity and conservation research at the NUS.

Contrary to the fears of your

correspondents, much emphasis has been placed on such issues at the NUS over the past decade and we think that Singapore is well equipped to tackle them.

We hope that the government of Singapore will continue its commitment to and funding of biodiversity research and conservation in this rich island nation. Lanna Cheng*, Damir Kovac $\dagger$

${ }^{*}$ Scripps Institution of Oceanography, University of California, San Diego, La Jolla, California 92093-0202, USA

†Forschungsinstitut Senckenberg, Senckenberganlage 25, 60325 Frankfurt am Main, Germany

\section{Photos may offer clues over Ethiopian fossil site}

Sir - Horst Seidler, in his Correspondence (Nature 411, 15; 2001) responding to the News story "Restrictions delay fossil hunts in Ethiopia” (Nature 410, 728; 2001), states that his use of the Galili research site in Ethiopia is legal. But I, not he, discovered this site, as shown in the accompanying photograph.

The Ethiopian Authority for Research and Conservation of Cultural Heritage, which regulates the use of sites, incorrectly assumed that Galili and the Mulu Basin are different, and has been persuaded to allow Seidler's occupation to continue.

After participating in the discovery of Galili in 1997, I worked there each year under official permit. Then, after my first publication from this site (Am. J. Phys. Anthrop. 111, Suppl. 30, 170; 2000), Seidler arrived there, camping less than 200 metres from the place where I had found hominid fossils two years earlier. Now he claims, incorrectly, that my permit was for a different area, although the photographs below clearly show his camp in the same area as my earlier site.

Seidler notes that after arriving at my site, he offered to let me join his team. This

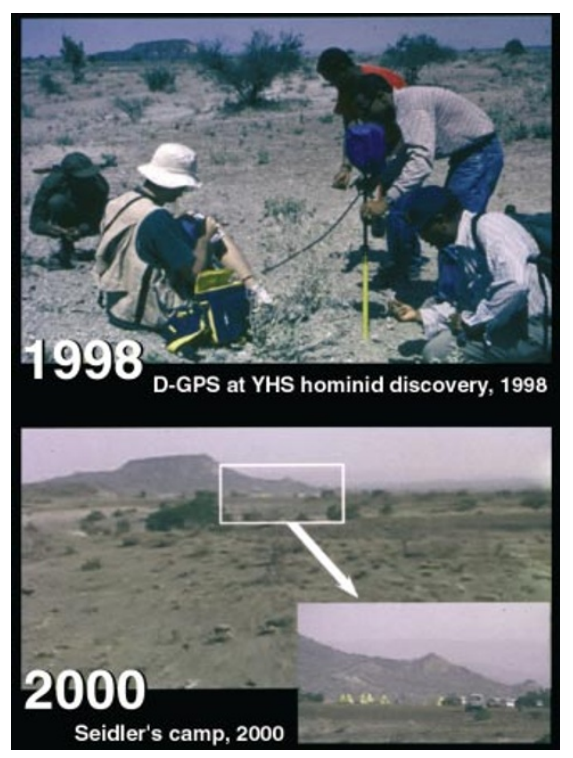

Digging in: Haile-Selassie's Galili camp, top, and Seidler's camp, bottom and inset. offer was completely inappropriate as the site was mine in the first place. It would have been far better for Professor Seidler to have withdrawn from Galili when I appealed to Ethiopian regulators about his team's arrival there. Instead, he first apologized for what happened, now claims that my permit was for a different area, and continues to occupy the site.

Yohannes Haile-Selassie

Laboratory for Human Evolutionary Studies, Department of Integrative Biology, University of California, Berkeley, California 94720, USA

\section{Keeping Mendel in mind}

Sir-Science is a function of cultural and social imprinting, the impression left by the environment in which a researcher lives and works. Johann Gregor Mendel lived in difficult circumstances, with his work neglected during his lifetime, and disregarded under the influence of Trofim Lysenko. Now, as your News story "Museum suffers spiritual cramps over Mendel's work" (Nature 410, 6; 2001) makes clear, the Mendel museum in Brno, the Mendelianum, is under threat on rather flimsy religious grounds.

After a recent international human genetics meeting in Vienna, I visited the the Mendelianum and the abbey where Mendel designed and performed the experiments forming the cornerstone of genetics. The museum is managed by cordial, enthusiastic people, but it is small and has limited resources compared with similar institutions in Eastern Europe, for example the museum dedicated to Ignaz Semmelweis in Budapest. Few of my colleagues at the Vienna meeting were interested in visiting the cradle of genetics, and there is an air of indifference in this lovely city towards such an illustrious citizen and his memorial.

Given the relevance and impact of genetics, most recently with the decoding of the human genome sequence, the scientific community, especially in Eastern Europe, must support the Mendelianum. A fund could be established, genetics meetings could be held in Brno, and promotional material could be distributed to research centres, museums and other institutions across the world. Hence, future generations will become culturally 'imprinted', not with the dogmatic ignorance of Lysenko's heirs, but with the work of this universal figure to whom we, as a rational species, owe so much.

\section{Fabio Salamanca}

Unit of Medical Research in Human Genetics, National Medical Center, Mexican Institute of Social Security, Apartado postal 12-951, Mexico DF 03020, Mexico 